\title{
Hubungan Gender dengan Strategi Pembelajaran Bahasa Arab dalam kalangan Pelajar Sekolah Menengah Agama di Terengganu
}

\author{
KAMARUL SHUKRI MAT TEH \\ Universiti Darul Iman Malaysia
}

\section{NIK MOHD RAHIMI NIK YUSOFF MOHAMED AMIN EMBI ZAMRI MAHAMOD}

Universiti Kebangsaan Malaysia

\begin{abstract}
Abstrak: Beberapa kajian yang merentasi pelbagai budaya menunjukkan bahawa pelajar perempuan lebih banyak dan kerap menggunakan Strategi Pembelajaran Bahasa (SPB) berbanding pelajar lelaki (Ehrman \& Oxford, 1989; Green \& Oxford, 1995). Namun begitu, terdapat kajian menunjukkan tiada perbezaan signifikan antara pelajar lelaki dan pelajar perempuan dalam penggunaan SPB (Chang, 1990; Chou, 2002). Malah, ada juga kajian menyimpulkan bahawa kadangkala pelajar lelaki lebih banyak menggunakan sesetengah strategi tertentu (Oxford, 1994; Wharton, 2000).Perbezaan linguistik seperti ortografi juga dapat mempengaruhi penggunaan strategi (Douglas, 1992; Grabe, 1986). Justeru, kertas ini memerihalkan dapatan kajian tentang penggunaan SPB dalam pembelajaran bahasa Arab berdasarkan perbezaan gender. Data dikumpulkan dengan menggunakan soal selidik kendiri Strategi Pembelajaran Bahasa Arab (SPBA) yang diadaptasi daripada SILL (Oxford, 1990). Subjek kajian yang dipilih secara rawak adalah terdiri daripada 460 orang pelajar Tingkatan 4 di 13 buah sekolah menengah agama di Terengganu.. Dapatan kajian menunjukkan pelajar perempuan lebih banyak menggunakan $S P B$ secara keseluruhan berbanding pelajar lelaki semasa mempelajari bahasa Arab. Kajian ini juga menunjukkan pelajar perempuan lebih kerap menggunakan strategi memori, afektif, dan metafizik berbanding pelajar lelaki. Tiada perbezaan signifikan pada penggunaan strategi kognitif, metakognitif, tampungan, dan sosial.
\end{abstract}


Abstract: Female students have reported that they use Language Learning Strategies (LLS) more often than male students in many studies across different cultures (Ehrman \& Oxford, 1989; Green \& Oxford, 1995). However, some studies have demonstrated no statistically significant difference between gender in the use of LLS (Chang, 1990; Chou, 2002). Yet others have shown that male students use more LLS than female students in certain strategy categories (Oxford, 1994; Wharton, 2000). Linguistics differences are also known to influence strategy use (Douglas, 1992; Grabe, 1986).This paper describes the LLS employed by students of Arabic language based on gender. The subjects comprised 460 Form 4 students from 13 religious secondary schools in Terengganu. Data were collected using an Arabic language learning strategy questionnaire adapted and modified from SILL (Oxford, 1990). The results of the study indicate that overall, female students of Arabic language tended to use LLS more frequently than male students. The result also showed that female students use more LLS than male students in the following three categories: memory, affective and metaphysical. However, no statistically significant differences were found in the use of cognitive, metacognitive, compensation and social strategies.

\section{PENGENALAN}

Strategi pembelajaran bahasa (SPB) ialah langkah atau tindakan khusus yang diambil oleh para pelajar untuk memudahkan pemerolehan, penyimpanan, pengingatan semula, dan penggunaan maklumat (Rigney, 1978) sehingga menjadikan pembelajaran lebih mudah, lebih cepat, lebih menyeronokkan, lebih kendiri, lebih efektif, dan lebih senang dipindahkan ke suasana baru (Oxford, 1990). Strategi tersebut melibatkan prosedur mental dan komunikatif untuk mempelajari dan menggunakan bahasa (Nunan, 1999) dalam kerangka mempertingkatkan pencapaian dan penguasaan bahasa sasaran (Mohamed Amin, 2000).

Beberapa kajian (Doering, 1999; Faizahani, 2002; Green \& Oxford, 1995; Griffiths 2003; Holt, 2005; Kamarul Shukri, Nik Mohd Rahimi, Mohamed \& Zamri., 2008; Nakanoko, 2004; Wharton, 2000) menunjukkan pelajar cemerlang bahasa menggunakan pelbagai SPB secara lebih kerap berbanding pelajar kurang cemerlang. Strategi tersebut dijangkakan boleh diajarkan kepada pelajar kurang 
cemerlang (O’Malley \& Chamot, 1990; Oxford, 1990). Pada waktu yang sama, beberapa faktor telah dikenal pasti dapat mempengaruhi penggunaan SPB (Oxford, 1990). Antaranya motivasi, jantina, latar belakang budaya, jenis tugasan, umur, tahap sosioekonomi, tahap pencapaian akademik dan seumpamanya.

\section{LATAR BELAKANG KAJIAN}

Berdasarkan beberapa penyelidikan awal tentang perbezaan gender ke atas kebolehan intelektual, motivasi, konsep-kendiri, dan perlakuan sosial, Maccoby dan Jacklin (1974) mendapati aptitud lisan perempuan lebih ketara berbeza berbanding lelaki. Kemahiran lisan perempuan bermula daripada zaman kanak-kanak dan menjadi semakin matang dengan cepat. Walau bagaimanapun, kajian-kajian terkini menunjukkan magnitud perbezaan gender adalah pelbagai, berdasarkan perbezaan tugasan atau populasi. Malah terdapat kajian menunjukkan ketiadaan signifikan perbezaan gender atas kebolehan lisan (Boocock, 1980). Dapatan seumpama ini menggalakkan para penyelidik SPB mengkaji bentuk corakan hasil daripada pengaruh gender ke atas pemilihan dan penggunaan SPB.

Kajian yang dilakukan oleh Oxford dan Nyikos (1989) ke atas lebih daripada 1200 pelajar prasiswazah yang mempelajari bahasa Perancis, Jerman, Itali, Sepanyol dan Rusia di Amerika Syarikat menunjukkan perbezaan gender mempunyai pengaruh yang besar dan ketara ke atas penggunaan SPB. Mereka mendapati pelajar perempuan lebih kerap menggunakan SPB berbanding pelajar lelaki. Politzer (1983) telah menjalankan kajian SPB ke atas 90 pelajar pra siswazah yang mempelajari bahasa Perancis, Sepanyol dan Jerman di salah sebuah universiti di pantai barat Amerika Syarikat. Beliau mendapati pelajar perempuan menggunakan strategi pembelajaran sosial lebih kerap berbanding pelajar lelaki. Dapatan ini sejajar dengan hasil kajian Ehrman dan Oxford (1989) yang dijalankan ke atas 79 orang dewasa - terdiri daripada pelajar, guru bahasa dan jurulatih bahasa profesional di US Foreign Service Institute.

Green dan Oxford (1995) telah menjalankan kajian ke atas 374 pelajar bahasa Inggeris sebagai bahasa kedua di Universiti Puerto Rico, Mayaguez. Hasil kajian beliau menunjukkan pelajar perempuan menggunakan strategi memori, metakognitif, afektif, dan sosial lebih kerap daripada pelajar lelaki. Kajian Bacon (1992) mengenai strategi yang digunakan semasa latihan mendengar teks 
asli dalam bahasa sasaran mendapati pelajar perempuan lebih banyak dan kerap menggunakan strategi metakognitif berbanding pelajar lelaki. Mereka gemar merancang untuk latihan pendengaran, memantau kefahaman, dan menilai strategi mereka. Manakala pelajar lelaki pula lebih kerap menggunakan strategi terjemahan berbanding pelajar perempuan.

Walau bagaimanapun, kajian Tran (1988) telah mengemukakan dapatan yang berbeza. Beliau mendapati pendatang lelaki Vietnam ke Amerika menggunakan lebih banyak SPB berbanding wanita Vietnam. Tran (1988) berpendapat, selain faktor gender dan etnik, keputusan kajian ini turut dipengaruhi oleh suasana tempat pekerjaan. Wharton (2000) pula menjalankan kajian penggunaan SPB ke atas 678 pelajar universiti yang mempelajari bahasa Jepun dan Perancis sebagai bahasa asing di Singapura. Kajian ini mendapati pelajar lelaki didapati lebih banyak menggunakan SPB berbanding pelajar perempuan. Wharton (2000) merumuskan apabila subjek kajian merupakan mereka yang berpengalaman dan matang maka perbezaan gender dalam penggunaan SPB tidak menjadi signifikan.

Kajian Osanai (2000) ke atas 147 pelajar asing di lima buah universiti di barat daya Amerika Syarikat menunjukkan secara statistiknya tiada perbezaan signifikan antara gender dalam penggunaan SPB secara keseluruhannya. Walau bagaimanapun, pelajar perempuan dilaporkan lebih kerap menggunakan strategi memori, kognitif, metakognitif, sosial dan afektif berbanding pelajar lelaki. Chou (2002) pula menjalankan kajian ke atas 474 pelajar kolej teknologi dan vokasional yang mempelajari bahasa Inggeris sebagai bahasa asing di Taiwan. Kajian menunjukkan tiada kesan signifikan daripada pemboleh ubah gender ke atas penggunaan SPB dalam kalangan pelajar.

Mohamed Amin (1996) telah menjalankan kajian SPB ke atas 515 pelajar sekolah menengah yang mempelajari bahasa Inggeris di Malaysia. Kajian ini mendapati SPB secara keseluruhan lebih banyak digunakan oleh pelajar perempuan berbanding pelajar lelaki. Pelajar perempuan juga didapati lebih banyak menggunakan strategi di dalam kelas, di luar kelas, dan untuk peperiksaan berbanding pelajar lelaki. Zamri (2004) pula menjalankan kajian SPB ke atas lapan pelajar Tingkatan 4 yang mempelajari bahasa Melayu di Malaysia. Kajiannya melaporkan pelajar lelaki lebih banyak menggunakan tema SPB ketika di dalam kelas, di luar kelas, dan untuk peperiksaan berbanding perempuan. 
Pelajar lelaki juga didapati lebih banyak menggunakan SPB dalam kemahiran mendengar dan menulis ketika di dalam kelas, di luar kelas, dan untuk peperiksaan. Pelajar perempuan pula lebih banyak menggunakan strategi dalam kemahiran membaca semasa di dalam kelas dan untuk peperiksaan.

Kebanyakan kerja penyelidikan SPB dijalankan di negaranegara Barat, dan ia masih berkurangan di Malaysia. Kajian tersebut lebih banyak dilakukan terhadap bahasa Inggeris, Sepanyol, Perancis dan Jerman. Manakala kajian ke atas bahasa Arab sama ada di dalam atau di luar Malaysia - hatta di negara-negara Arab sekalipun - adalah sedikit. Dalam konteks pembelajaran bahasa di Malaysia, kajian SPB lebih banyak dijalankan ke atas bahasa Inggeris (Soars, 1995; Mohamed Amin, 1996; Radha Nambiar, 1996) dan bahasa Melayu (Abu Talib, 1998; Mohd Nazali, 1999; Zamri, 2004), sedangkan kajian dalam pendidikan bahasa Arab masih kurang, lebih-lebih lagi yang berkaitan dengan pengaruh gender terhadap penggunaan SPB.

Kekurangan kajian SPB dalam konteks pembelajaran bahasa Arab dan keinginan untuk menerokai bentuk hubungan perbezaan gender dengan penggunan SPB dalam bahasa tersebut merupakan antara faktor yang mendorong kajian ini dilakukan. Selain itu, perbezaan jenis bahasa dari segi linguistik dan ortografi turut mempengaruhi penggunaan strategi dalam pembelajaran bahasa sasaran (Douglas, 1992; Grabe, 1986). Keadaan ini dapat dilihat dalam pembelajaran bahasa Arab di Malaysia. Perbezaan antara bahasa Melayu dan bahasa Arab dari segi linguistik dan ortografi menyebabkan SPB yang kerap digunakan dan berkesan dalam pembelajaran bahasa Melayu tidak semestinya kerap dan berkesan penggunaannya dalam pembelajaran bahasa Arab. Justeru, kajian SPB dalam pembelajaran bahasa Arab secara umum dan berdasarkan perbezaan jantina perlu dilakukan. Di samping itu, kajian ini diharapkan dapat membantu untuk memperbaiki prestasi pencapaian bahasa Arab (Kamarul Shukri et al., 2008) yang dikatakan semakin menurun (Nasimah, 2006; Saupi, 2003; Wan Abrisam, 2002) dengan memanfaatkan dapatan kajian ini secara teratur dan terancang. Umpamanya, strategi pembelajaran yang didapati berkesan dan kerap digunakan oleh gender tertentu boleh diajarkan kepada kumpulan pelajar tersebut. Berdasarkan kaedah ini, pembelajaran bahasa dapat dipermudahkan, pencapaian pelajar dapat dipertingkatkan, dan pelajar akan menjadi lebih kendiri. Sekali gus, ia mampu menjadikan pembelajaran bahasa Arab di Malaysia lebih efektif, dinamik, dan menarik. 


\section{OBJEKTIF KAJIAN}

Objektif kajian yang dijalankan adalah untuk menentukan sama ada terdapat perbezaan signifikan pada tahap penggunaan SPB secara keseluruhan dan mengikut kategori strategi utama berdasarkan gender dalam kalangan para pelajar sekolah menengah agama ketika mempelajari bahasa Arab.

\section{SOALAN KAJIAN}

Kajian ini bertujuan untuk menjawab dua soalan, iaitu:

1. Adakah terdapat perbezaan signifikan pada penggunaan SPB secara keseluruhan semasa mempelajari bahasa Arab dalam kalangan pelajar sekolah menengah agama berdasarkan perbezaan gender?

2. Adakah terdapat perbezaan signifikan pada penggunaan SPB mengikut kategori strategi utama: memori, kognitif, tampungan, metakognitif, afektif, sosial dan metafizik semasa mempelajari bahasa Arab dalam kalangan pelajar sekolah menengah agama berdasarkan perbezaan gender?

\section{METODOLOGI}

Kajian kuantitatif ini dijalankan di sekolah-sekolah menengah agama di Terengganu. Ia melibatkan pelajar Tingkatan 4 di 13 buah sekolah menengah agama Terengganu. Berdasarkan Jadual Penentuan Saiz Sampel Krejcie dan Morgan (1970), bilangan sampel yang diperlukan dalam kajian ini (yang mempunyai jumlah populasi 1691 orang) adalah seramai 313 orang. Bagi meningkatkan ketepatan penyelidikan maka seramai 460 orang sampel telah dipilih secara rawak. Setiap strata jantina diwakili oleh 230 orang pelajar.

Instrumen soal selidik telah digunakan bagi mengumpul maklumat tentang penggunaan strategi pembelajaran bahasa Arab dalam kalangan para pelajar sekolah menengah agama. Soal selidik tersebut dibina berdasarkan gagasan yang terdapat di dalam SILL versi 7.0 (Oxford, 1990). Selain enam konstruk yang terdapat di dalam SILL (seperti Memori, Kognitif, Tampungan, Metakognitif, Sosial, dan Afektif), pengkaji juga telah menambahkan satu konstruk yang dinamakan sebagai Metafizik. Konstruk ini dibina 
hasil daripada penelitian keumuman tabii pembelajaran bahasa Arab dan keunikan tingkah laku pembelajaran bahasa tersebut di Malaysia (Kamarul Shukri, 2006; Kamarul Shukri \& Mohd Hazli, 2008). Sementelahan pula, bahasa adalah sebahagian daripada budaya, dan budaya adalah sebahagian daripada bahasa. Kedua-duanya saling berkait dan tidak boleh dipisahkan tanpa menjejaskan kesignifikan salah satu daripadanya (Brown, 1994). Ikatan hubungan ini semakin kuat apabila ia dikaitkan dengan agama. Senario ini cukup jelas dalam bahasa Arab apabila perhubungan antara agama, bahasa Arab, dan budaya merupakan hubungan timbal balas yang tidak boleh diceraikan. Keadaan ini mempengaruhi proses pembelajaran pelajar beragama Islam yang mempelajari bahasa Arab dalam persekitaran budaya dan amalan keagamaan dipraktikkan.

Dalam konteks pembelajaran bahasa Arab di Malaysia, domain yang terbentuk hasil daripada hubungan antara agama, ibadah, dan bahasa telah melahirkan pelbagai strategi pembelajaran yang didorong oleh faktor keagamaan dan amalan ibadah yang berkait rapat dengan bahasa sasaran. Tindakan dan operasi pembelajarannya yang berkait dengan ciri-ciri abstrak, maakulat, dan ketuhanan mewajarkan domain tersebut dikenali sebagai metafizik. Ia merupakan strategi berunsurkan ketauhidan dan pengakuan tentang ilahiyyat atau ketuhanan yang membolehkan pelajar memanipulasi pembelajaran bahasa secara berterusan melalui rangsangan, dorongan, dan amalan keagamaan. Oleh itu, kajian ini mendefinisikan strategi metafizik sebagai tindakan atau operasi dalam pembelajaran yang didorong oleh faktor keagamaan dan amalan ibadah yang berkait rapat dengan bahasa sasaran (Kamarul Shukri, 2009). Pemilihan, pengkoordinasian, dan penggunaan strategi metafizik yang sesuai mampu mempertingkatkan kemahiran, penguasaan, dan pencapaian bahasa. Untuk kajian ini, lapan item atau strategi telah dipilih bagi membentuk konstruk metafizik, iaitu strategi:

1. Berlatih untuk mengenal pasti kaedah nahu (sintaksis) atau sarf (morfologi) yang digunakan semasa membaca al-Qur'an,

2. Berlatih untuk mengenal pasti kaedah sistem penulisan Arab (imla') yang digunakan semasa membaca al-Qur'an,

3. Berlatih untuk mengenal pasti sebab penggunaan kaedah tatabahasa Arab semasa membaca al-Qur'an, 4. Berusaha untuk memahami atau menghayati makna bacaan dalam sembahyang, doa, ayat al-Qur' an atau al-Hadith, 
5. Membaca al-Qur'an setiap hari untuk memperbetul atau melancarkan sebutan bahasa Arab saya,

6. Membaca ayat al-Qur'an atau doa untuk menghilangkan rasa gugup atau tertekan ketika mempelajari bahasa Arab,

7. Bersembahyang hajat atau berdoa pada Allah agar saya berjaya dalam pembelajaran bahasa Arab, dan

8. Meminta restu daripada guru sebelum menduduki peperiksaan.

Strategi-strategi metafizik ini turut dikesani oleh kajian Abu Talib (1998), Supian (2003), dan Zamri (2004) yang dilakukan ke atas para pelajar bahasa Melayu di Malaysia. Tetapi, kajian mereka hanya lebih tertumpu kepada amalan keagamaan untuk mengawal kekhuatiran bahasa, meningkatkan keyakinan, dan bersifat afektif. Manakala item-item strategi metafizik di dalam kajian ini pula turut melibatkan aspek sub-sub strategi yang lain. Antaranya, penggunaan semula maklumat bahasa, penghayatan aspek bahasa, pengurusan pembelajaran, dan interaksi sosio-afektif.

Soal selidik yang dibina telah ditentukan kesahan muka dan kesahan kandungan oleh empat orang pakar dalam bidang pendidikan bahasa Arab, bahasa Inggeris sebagai bahasa kedua, bahasa Melayu dan SPB. Di samping itu, satu kajian rintis telah dijalankan ke atas 49 orang pelajar sekolah menengah agama bagi menguji kebolehtadbiran instrumen, mendapatkan kesahan muka, dan menentukan indeks kebolehpercayaan. Nilai pekali kebolehpercayaan Alfa Cronbach yang diperoleh bagi setiap konstruk adalah antara julat indeks 0.650 hingga 0.954. Indeks kebolehpercayaan ini adalah tinggi dan boleh diterima pakai (McMillan \& Schumacher, 2006; Sekaran, 1992).

\section{ANALISIS DATA}

Ujian MANOVA digunakan untuk mengenal pasti bentuk hubungan gender dengan penggunaan SPB oleh pelajar sekolah menengah agama ketika mempelajari bahasa Arab. Ujian tersebut dijalankan bagi menguji dua hipotesis nol yang menyatakan:

1. Tiada perbezaan signifikan dalam penggunaan SPB secara keseluruhan berdasarkan perbezaan gender. 
2. Tiada perbezaan signifikan dalam penggunaan SPB mengikut kategori strategi utama berdasarkan perbezaan gender.

Sebelum ujian MANOVA dapat dilakukan, beberapa perkara atau andaian yang menjadi prasyarat ujian tersebut perlu diperiksa. Antara perkara tersebut ialah saiz sel, taburan normal univariat dan multivariat, ketiadaan data terpencil, tahap multikolinearan dan singulariti (Coakes 2005; Field,2005; Hair, Anderson, Tatham \& Black, 1998; Pallant, 2001). Semasa menjalankan ujian normaliti Multivariat tiga kes yang menunjukkan nilai ekstrem dan menjadi data terpencil telah disisihkan. Hal ini merujuk kepada "Jarak Mahalanobis" melalui kaedah "Regresi: Statistik Residual". Oleh itu, jumlah kes yang dianalisis bagi menjawab soalan kajian satu dan dua adalah seramai 457 orang pelajar. Syarat-syarat lain seperti yang disebut di atas juga telah diteliti dan dipenuhi.

Seterusnya, ujian bagi menentukan matrik kehomogenan varian kovarian telah dilakukan dengan menggunakan ujian Box's M. Hasil ujian tersebut menunjukkan tidak terdapat perbezaan varian kovarian yang signifikan dalam kalangan pemboleh ubah bersandar merentasi pemboleh ubah bebas $(\mathrm{F}=1.24, \mathrm{p}=0.064)(\mathrm{p}$ $>0.05$ ). Ini bermakna, varian kovarian pemboleh ubah bersandar adalah homogenus merentasi pemboleh ubah bebas. Lantaran itu, ujian MANOVA boleh dijalankan bagi menjawab soalan kajian di atas.

Ujian Levene turut dijalankan bagi melihat kesamaan varian bagi setiap kategori pemboleh ubah bersandar yang dikaji. Hasil ujian Levene menunjukkan bahawa nilai yang diperolehi adalah $\mathrm{F}=0.724$, Sig. $=0.538>0.05$ (memori) $; \mathrm{F}=3.699$, Sig. $=0.012$ $<0.05$ (kognitif); $F=0.966$ Sig. $=0.409>0.05$ (tampungan); $F=$ 1.160, Sig. $=0.325>0.05$ (metakognitif); $F=1.287$, Sig. $=0.278>$ 0.05 (afektif); F = 1.789, Sig.= $0.149>0.05$ (sosial); dan $F=2.698$, Sig. $=0.045<0.05$ (metafizik). Nilai signifikan pada lima pemboleh ubah bersandar iaitu memori, tampungan, metakognitif, afektif, dan sosial adalah lebih besar daripada 0.05. Ini menunjukkan pembolehpemboleh ubah tersebut mempunyai varian yang sama. Manakala nilai signifikan pada dua pemboleh ubah bersandar yang lain, iaitu kognitif dan metafizik pula adalah lebih kecil daripada 0.05. Ia menunjukkan terdapat perbezaan varian pada kedua-dua pemboleh ubah tersebut (Coakes, 2005; Pallant, 2001; Tabachnick \& Fidell, 2001). 
Memandangkan kajian ini melibatkan jumlah sampel yang besar maka perbezaan varian $($ Sig.< 0.05$)$ tidak menjadi halangan bagi menjalankan ujian MANOVA. Namun begitu, dapatan MANOVA bagi pemboleh ubah yang memiliki perbezaan varian tersebut perlu diuji semula dengan menggunakan ujian Univariat/ ANOVA dengan cara menurunkan nilai alfa 0.05 kepada 0.025 ataupun 0.01 untuk mengukuhkan lagi dapatan MANOVA yang dijalankan (Pallant, 2001; Tabachnick \& Fidell, 2001).

Berdasarkan Jadual 1, nilai yang diperoleh daripada ujian Multivariat bagi penggunaan SPB berdasarkan gender adalah Wilks' Lambda $=0.959, \mathrm{~F}(7,447)=2.763$, dan Sig. $=0.008(\mathrm{p}<0.05)$. Nilai tersebut menunjukkan bahawa hipotesis nol pertama (Ho.1) berjaya ditolak. Ini menunjukkan terdapat perbezaan signifikan pada tahap penggunaan SPB secara keseluruhan berdasarkan perbezaan gender para pelajar sekolah menengah agama semasa mereka mempelajari bahasa Arab.

Jadual 1. Analisis MANOVA Perbezaan Penggunaan SPB Berdasarkan Gender $(N=457)$

\begin{tabular}{lccccc}
\hline Kesan & $\begin{array}{c}\text { Nilai Wilks' } \\
\text { Lambda }\end{array}$ & Nilai F & $\begin{array}{c}\text { D.K. Antara } \\
\text { Kumpulan }\end{array}$ & $\begin{array}{c}\text { D.K. Dalam } \\
\text { Kumpulan }\end{array}$ & $\begin{array}{c}\text { Tahap } \\
\text { Sig. }\end{array}$ \\
\hline Gender & 0.959 & 2.763 & 7 & 447 & 0.008 \\
\hline
\end{tabular}

Sig. pada aras 0.05

Bagi mengetahui sama ada perbezaan penggunaan SPB berdasarkan perbezaan gender berlaku ke atas kesemua kategori utama SPB atau hanya pada kategori yang tertentu sahaja, maka pemeriksaan lanjutan ke atas setiap pemboleh ubah bersandar perlu dilakukan (Pallant, 2001; Coakes, 2005). Jadual 2 menunjukkan hasil keputusan ujian Univariat bagi setiap pemboleh ubah bersandar. Ujian yang dijalankan memaparkan nilai yang diperoleh adalah $\mathrm{F}$ $(1,453)=4.403$, Sig. $=0.036<0.05$ (memori), F $(1,453)=11.243$, Sig. $=0.001<0.05$ (afektif), dan F $(1,453)=9.667$, Sig. $=0.002<$ 0.05 (metafizik). Nilai kesignifikan $\mathrm{p}<0.05$ membolehkan hipotesis nol kedua (Ho.2) berjaya ditolak. Sekaligus, ia menunjukkan terdapat perbezaan signifikan dalam penggunaan SPB pada kategori strategi utama memori, afektif, dan metafizik berdasarkan perbezaan gender semasa para pelajar sekolah menengah agama mempelajari bahasa Arab. 
Jadual 2. Kesan Gender ke atas Penggunaan Kategori Utama SPB $(N=457)$

\begin{tabular}{|c|c|c|c|c|c|c|}
\hline $\begin{array}{c}\text { Pemboleh } \\
\text { Ubah Bebas }\end{array}$ & $\begin{array}{c}\text { Pemboleh Ubah } \\
\text { Bersandar }\end{array}$ & $\begin{array}{c}\text { Jumlah } \\
\text { Kuasa Dua }\end{array}$ & D.K. & $\begin{array}{c}\text { Min Kuasa } \\
\text { Dua }\end{array}$ & Nilai $\mathbf{F}$ & Sig. \\
\hline \multirow[t]{7}{*}{ Gender } & Memori & 1.526 & 1 & 1.526 & 4.403 & 0.036 \\
\hline & Kognitif & 0.685 & 1 & 0.685 & 1.909 & 0.168 \\
\hline & Tampungan & 0.139 & 1 & 0.139 & 0.172 & 0.679 \\
\hline & Metakognitif & 1.360 & 1 & 1.360 & 3.081 & 0.080 \\
\hline & Afektif & 4.992 & 1 & 4.992 & 11.243 & 0.001 \\
\hline & Sosial & 1.108 & 1 & 1.108 & 2.177 & 0.141 \\
\hline & Metafizik & 4.945 & 1 & 4.945 & 9.667 & 0.002 \\
\hline
\end{tabular}

Sig. pada aras 0.05

Keputusan ujian Tests of Between-Subjects Effects (rujuk Jadual 2) menunjukkan terdapatnya perbezaan tahap penggunaan SPB dalam strategi utama memori, afektif, dan metafizik berdasarkan perbezaan gender. Memandangkan perbezaan signifikan tersebut hanya melibatkan dua tahap dalam pemboleh ubah bebas maka ujian Post-hoc tidak perlu dijalankan. Sebaliknya, penentuan tahap manakah yang sebenarnya berbeza bagi setiap pemboleh ubah bersandar tersebut boleh dilihat melalui analisis Estimated Marginal Means. Berdasarkan Jadual 3, dapatlah diketahui bahawa pelajar perempuan menggunakan lebih banyak strategi memori, afektif, dan metafizik secara kerap berbanding pelajar lelaki.

Jadual 3. Perbandingan Kategori Utama SPB Berdasarkan Gender $(N=457)$

\begin{tabular}{llcc}
\hline Pemboleh Ubah Bersandar & Gender & Min & Sisihan Piawai \\
\hline Memori & Lelaki & 1.93 & 0.04 \\
& Perempuan & 2.05 & 0.03 \\
Kognitif & Lelaki & 2.00 & 0.04 \\
Tampungan & Perempuan & 2.08 & 0.04 \\
& Lelaki & 2.69 & 0.06 \\
Metakognitif & Perempuan & 2.73 & 0.06 \\
\multirow{3}{*}{ Afektif } & Lelaki & 1.98 & 0.04 \\
& Perempuan & 2.09 & 0.04 \\
Sosial & Lelaki & 2.27 & 0.04 \\
& Perempuan & 2.49 & 0.04 \\
Metafizik & Lelaki & 2.02 & 0.04 \\
& Perempuan & 2.12 & 0.04 \\
& Lelaki & 2.55 & 0.04 \\
\hline
\end{tabular}


Seperti yang ditunjukkan oleh hasil ujian Levene dalam analisis MANOVA sebelum ini, terdapat dua pemboleh ubah bersandar yang mempunyai perbezaan varian iaitu kognitif (Sig.= $0.012<0.05$ ) dan metafizik (Sig. $0.045<0.05$ ). Perbezaan varian ini tidak menjadi penghalang untuk meneruskan ujian MANOVA sekiranya jumlah sampel adalah besar. Namun begitu, perbezaan tersebut perlu diuji semula dengan menggunakan ujian ANOVA yang diturunkan nilai alfa 0.05 kepada 0.025 ataupun 0.01 . Ujian ini bertujuan untuk mengukuhkan dapatan MANOVA terhadap pemboleh ubah berkenaan (Pallant, 2001; Tabachnick \& Fidell, 2001).

Hasil ujian Levene pada tahap signifikan 0.01 menunjukkan bahawa tidak terdapat perbezaan varian pada pemboleh ubah bersandar kognitif $(F=3.699$, Sig. $=0.012>0.01)$ dan metafizik $(F$ $=2.698$, Sig. $=0.045>0.01)$. Seterusnya, hasil ujian ANOVA pada aras signifikan 0.01 untuk penggunaan strategi kognitif berdasarkan faktor gender menunjukkan nilai yang diperoleh adalah $\mathrm{F}(1,453)$ $=1.909$, Sig. $=0.168>0.01$ (rujuk Jadual 4). Nilai ini menunjukkan tidak wujudnya perbezaan signifikan pada penggunaan strategi kognitif berdasarkan perbezaan gender dalam kalangan para pelajar sekolah menengah agama.

Jadual 4. ANOVA (Ujian Lanjutan MANOVA): Penggunaan SPB (Kognitif) Berdasarkan Gender $(N=457)$

\begin{tabular}{lccccc}
\hline $\begin{array}{c}\text { Pemboleh Ubah } \\
\text { Bebas }\end{array}$ & $\begin{array}{c}\text { Jumlah Kuasa } \\
\text { Dua }\end{array}$ & D.K. & $\begin{array}{c}\text { Min Kuasa } \\
\text { Dua }\end{array}$ & Nilai F & Sig. \\
\hline Gender & 0.685 & 1 & 0.685 & 1.909 & 0.168 \\
\hline
\end{tabular}

Sig. pada aras 0.01

Jadual 5 pula menunjukkan hasil ujian ANOVA untuk penggunaan strategi metafizik berdasarkan faktor gender pada aras signifikan 0.01. Nilai yang diperoleh $\mathrm{F}(1,453)=9.667$, Sig. $=$ $0.002<0.01$ menunjukkan terdapatnya perbezaan signifikan pada penggunaan strategi metafizik dalam kalangan para pelajar sekolah menengah agama berdasarkan perbezaan tahap gender.

Jadual 5. ANOVA (Ujian Lanjutan MANOVA): Penggunaan SPB (Metafizik) Berdasarkan Gender $(N=457)$

\begin{tabular}{cccccc}
\hline $\begin{array}{c}\text { Pemboleh Ubah } \\
\text { Bebas }\end{array}$ & $\begin{array}{c}\text { Jumlah Kuasa } \\
\text { Dua }\end{array}$ & $\begin{array}{c}\text { D.K. } \\
\text { Min Kuasa } \\
\text { Dua }\end{array}$ & Nilai F & Sig. \\
\hline Gender & 4.945 & 1 & 4.945 & 9.667 & 0.002 \\
\hline
\end{tabular}

Sig. pada aras 0.01 
Kedua-dua ujian ANOVA yang menggunakan aras keyakinan yang lebih tinggi (99\%) telah menghasilkan keputusan yang sama dengan dapatan ujian MANOVA. Oleh itu, keputusan ujian MANOVA pada aras signifikan 0.05 adalah boleh dipercayai dan disokong oleh ujian ANOVA pada aras signifikan 0.01.

\section{PERBINCANGAN DAN RUMUSAN}

Kajian ini menunjukkan bahawa pelajar perempuan menggunakan SPB secara signifikan dan kerap berbanding pelajar lelaki semasa mempelajari bahasa Arab. Dapatan ini adalah konsisten dengan hasil beberapa kajian yang dilakukan sama ada di Malaysia (mis. Abu Talib, 1998; Faizahani, 2002; Mohamed Amin, 1996; Mohd Nazali, 1999; Punithavalli, 2003) atau di luar negara (mis. Chiang, 2004; Griffiths, 2003; Lan \& Oxford, 2005; Lu, 2007; Su, 2002; $\mathrm{Wu}, 2006)$. Walaupun begitu, ia tidak selari dengan beberapa kajian yang mendapati pelajar lelaki lebih banyak menggunakan SPB berbanding pelajar perempuan (mis. Oxford, 1994; Tran, 1988; Wharton, 2000; Zamri, 2004). Dapatan tersebut juga tidak sejajar dengan dapatan beberapa kajian yang menunjukkan tiada perbezaan signifikan dalam penggunaan SPB secara keseluruhan berdasarkan perbezaan gender (mis. al-Otaibi, 2004; al-Wahibee, 2000; Chang, 1990; Chou, 2002; Hong, 2006; Nakanoko, 2004; Nisbet, 2002; Osanai, 2000; Sima, 2008).

Terdapat kajian yang menunjukkan bahawa pencapaian pelajar perempuan dan lelaki adalah setanding di peringkat sekolah rendah. Pencapaian mereka mula berbeza mengikut mata pelajaran di peringkat sekolah menengah. Pelajar perempuan didapati terus maju dari segi keupayaan membaca dan pemerolehan bahasa. Manakala pelajar lelaki pula menandingi mereka dari segi pencapaian dalam mata pelajaran Sains dan Matematik (Fagerlind \& Saha, 1989). Kemahiran dan kebolehan lisan perempuan didapati lebih semula jadi dan ketara berbanding lelaki (Maccoby \& Jacklin, 1974). Aptitud lisan tersebut menjadikan pelajar perempuan banyak menggunakan bahasa dan kerap menggunakan SPB. Oxford (1989) mengandaikan orientasi sosial, kemahiran verbal, dan keakuran dengan norma linguistik serta akademik yang kuat dalam kalangan pelajar perempuan merupakan faktor penyebab berlakunya perbezaan penggunaan SPB berdasarkan gender. Mereka juga didapati lebih bersikap positif terhadap pembelajaran bahasa kedua berbanding pelajar lelaki (Gardner, 1985). 
Kesemua keterangan yang dikemukakan mampu menjustifikasikan dapatan bahawa pelajar perempuan lebih kerap menggunakan SPB secara keseluruhan berbanding pelajar lelaki. Ciri-ciri kemahiran lisan yang semula jadi, keinginan yang tinggi untuk meningkatkan kemahiran berbahasa, dan bersikap aktif lagi dinamik telah menjadikan mereka lebih berjaya dalam pembelajaran bahasa dan lebih kerap menggunakan SPB berbanding pelajar lelaki.

Pandangan Cross (1983) tentang perkaitan perbezaan gender dalam pencapaian bahasa dengan gender guru bahasa yang bertindak sebagai "role model" juga boleh menjustifikasikan dapatan kajian ini. Beliau berpendapat guru perempuan akan menjadi model ikutan positif untuk pelajar perempuan, tetapi tidak bagi pelajar lelaki dan begitu juga sebaliknya. Jadual 6 menunjukkan bahawa jumlah guru perempuan di sekolah-sekolah menengah agama di Terengganu adalah melebihi tiga kali ganda daripada jumlah guru lelaki. Perbezaan ketara jumlah guru perempuan berbanding guru lelaki menjelaskan bahawa pembelajaran bahasa pelajar perempuan lebih dipengaruhi oleh guru yang sama gender dengan mereka. Pelajar yang diajar oleh guru yang sama gender berhadapan dengan halangan sosial yang kurang untuk bertanya, meminta penjelasan, atau ulangan daripada guru tersebut. Keadaan ini mungkin mendorong pelajar yang memiliki gender tersebut menggunakan SPB lebih kerap berbanding pelajar gender lain. Bahkan dalam keadaan tertentu ia memaparkan ketiadaan perbezaan signifikan dalam penggunaan strategi berdasarkan perbezaan gender. Kajian ini sejajar dengan kajian al-Wahibee (2000) dan al-Otaibi (2004) yang dijalankan ke atas pelajar bahasa Inggeris di Arab Saudi. Sistem pengasingan kelas berdasarkan gender dan hanya guru yang sama gender sahaja yang mengajar bahasa Inggeris kepada pelajar telah mengujudkan model positif bahasa dan menghilangkan faktor negatif bagi setiap gender (Cross, 1983).

Jadual 6. Taburan Guru Sekolah Menengah Agama Di Terengganu Berdasarkan Gender

\begin{tabular}{lccc}
\hline & $\begin{array}{c}\text { Ikhtisas } \\
\text { Perguruan }\end{array}$ & $\begin{array}{c}\text { Tanpa Ikhtisas } \\
\text { Perguruan }\end{array}$ & Jumlah \\
\hline Lelaki & 81 & 95 & $176(24.58 \%)$ \\
Perempuan & 132 & 408 & $540(75.42 \%)$ \\
Jumlah & $213(29.75 \%)$ & $503(70.25 \%)$ & $716(100 \%)$ \\
\hline
\end{tabular}

Sumber: Jabatan Hal Ehwal Agama Terengganu (2007) 
Pada peringkat kategori strategi utama, pelajar perempuan didapati menggunakan lebih banyak strategi memori, afektif, dan metafizik secara kerap berbanding pelajar lelaki. Dapatan ini menyokong beberapa kajian yang telah dijalankan, seperti oleh Green dan Oxford (1995), dan Osanai (2000). Kajian Hashim dan Sahil (1994) pula menunjukkan pelajar perempuan menggunakan strategi afektif lebih kerap berbanding pelajar lelaki.

Antara andaian yang boleh dikemukakan ialah pelajar perempuan mempunyai kekuatan ingatan dan perasaan yang kuat berbanding pelajar lelaki. Mereka mampu mengingati sesuatu perkara dan tidak mudah melupakannya walaupun isunya kecil dan melepasi tempoh yang lama. Kajian Azhar et al. (2008) menunjukkan bahawa pelajar perempuan lebih ramai memiliki kamus bahasa Arab berbanding pelajar lelaki. Dapatan ini menjelaskan keinginan pelajar perempuan untuk menyimpan dan mengingati perkataan-perkataan baru adalah lebih tinggi berbanding pelajar lelaki. Justeru, mereka menggunakan lebih banyak strategi memori dalam pembelajaran bahasa Arab berbanding pelajar lelaki. Perasaan pelajar perempuan yang mudah tersentuh dan peka kepada persekitaran menyebabkan mereka mempunyai pengalaman untuk menangani perkara yang mempunyai hubung kait dengan perasaan dan emosi. Kekuatan ini dimanipulasikan dengan sebaiknya oleh pelajar perempuan dalam pembelajaran bahasa sehingga membolehkan mereka menggunakan strategi memori dan afektif dengan kerap dan pelbagai. Keadaan ini berbeza dengan pelajar lelaki yang mungkin kurang mengambil berat untuk mengingati perkara-perkara kecil dan cakna dengan perasaan orang lain atau diri sendiri.

Orientasi pendidikan sekolah agama lebih menjurus ke arah penghayatan ajaran Islam. Para pelajarnya sentiasa diberi penekanan tentang amalan ibadah dan syiar agama. Budaya setempat yang sentiasa memelihara adat dan norma kehidupan wanita timur pula menjadikan pelajar perempuan lebih banyak berada di rumah atau asrama (Mohd Anuar, 2005). Keadaan ini telah memberi lebih banyak peluang kepada pelajar perempuan untuk aktiviti keagamaan yang secara langsung melibatkan bahasa Arab. Aktiviti menghafal al-Quran, hadis, doa dan beribadah menjadikan mereka lebih kerap berinteraksi dengan bahasa agama. Oleh itu, pelajar perempuan mempunyai banyak peluang untuk mempraktikkan strategi metafizik berbanding pelajar lelaki yang mungkin terikat dengan beberapa aktiviti dan program sendiri serta luar sekolah. Justifikasi ini disokong oleh kajian al-Otaibi (2004) yang mendapati 
faktor budaya Arab menjadi penyebab pelajar perempuan di Arab Saudi lebih banyak menggunakan SPB di luar kelas berbanding pelajar lelaki. Budaya Arab yang menyebabkan pelajar perempuan lebih banyak berada di dalam rumah telah memberi peluang kepada mereka untuk melakukan pelbagai aktiviti bahasa dan penggunaan SPB. Manakala pelajar lelaki yang sibuk dengan aktiviti luar rumah pula, tidak mendapat peluang sedemikian rupa.

\section{IMPLIKASI KAJIAN}

Perbezaan tahap penggunaan SPB berdasarkan faktor gender membuktikan bahawa teori SPB turut didokong oleh teori kognitif sosial. Ia jelas membuktikan faktor sosial seperti gender mempunyai pengaruh terhadap tahap penggunaan SPB. Justeru, pembelajaran bahasa Arab di sekolah-sekolah menengah agama tidak harus mengekalkan status quo yang ada. Ciri-ciri inovasi perlu diterapkan dalam program latihan dalam perkhidmatan dan pembangunan guru dengan menggabungkan maklumat mengenai SPB ke dalam bidang pedagogi.

Perbezaan tahap penggunaan SPB berdasarkan gender memungkinkan kita menyarankan penggunaan SPB oleh pelajar dari dua sudut. Pertama, guru perlu menunjukkan jenis dan cara penggunaan strategi oleh pelajar cemerlang bahasa bagi setiap jantina. Sehubungan itu, pelajar digalakkan agar mengaplikasikan strategi yang digunakan oleh pelajar cemerlang dari kumpulan jantina yang sama. Kedua, guru sentiasa mengalakkan pelajar lelaki dan perempuan membina strategi pembelajaran mereka secara efektif tanpa terikat dengan ciri gender yang stereotaip. Strategi yang didapati kurang digunakan oleh kumpulan jantina tertentu perlu dicuba oleh kumpulan jantina lain. Justeru, guru hendaklah mempelbagaikan strategi dan kaedah pengajaran serta memberi peneguhan positif atau negatif bersesuaian dengan perbezaan jantina pelajar.

Memandangkan pemilihan dan penggunaan SPB kebiasaannya berkaitan dengan faktor individu seperti gender dan lain-lain, maka pengajaran bahasa tidak harus mengabaikan elemen perbezaan individu. Mereka yang terlibat dalam pendidikan bahasa perlu memahami tentang pengaruh faktor-faktor tersebut terhadap penggunaan SPB supaya latihan strategi yang ditawarkan menjadi lebih efisien dan sesuai dengan keperluan dan keadaan pelajar. 
Melalui cara ini pelajar akan diberi peluang untuk menggunakan pelbagai strategi secara kerap dan menuju ke arah kejayaan pembelajaran bahasa dengan mudah lagi menyeronokkan.

\section{RUJUKAN}

Abu Talib Abdullah. (1998). Gaya dan strategi pembelajaran bahasa Melayu di kalangan pelajar tingkatan 4 daerah Johor Bahru. Unpublished master's project, Universiti Kebangsaan Malaysia.

al-Otaibi, Ghazi Nawar. (2004). Language learning strategy use among Saudi EFL students and its relationship to language proficiency level, gender and motivation. Unpublished doctoral dissertation, Indiana University of Pennsylvania.

al-Wahibee, Khalid M. (2000). The relationship between language learning strategies and the English language oral proficiency of Saudi university level ESL students. Unpublished master's thesis, University of Kansas.

Azhar Hj Ahmad, Hossen Marip \& Morsalin Pawi. (2008). Kajian tinjauan pelaksanaan pengajaran dan pembelajaran bahasa Arab di sekolah menengah di negeri Sarawak. Prosiding Wacana Pendidikan Islam Siri 6, 635-645.

Bacon, S. M. (1992). The relationship between gender, comprehension, processing strategies, and cognitive and affective response in foreign language listening. The Modern Language Journal, 76 (2) 160-178.

Boocock, S. S. (1980). Sociology of education. Boston: Houghton Miflin.

Brown, H. D. (1994). Principles of language learning and teaching. Englewood Cliffs, NJ: Prentice Hall.

Chang, S. (1990). A study of language learning behaviors of Chinese students at the University of Georgia and the relation of those behaviors to oral proficiency and other factors. Unpublished doctoral dissertation, University of Georgia, Athens.

Chiang, H-H. (2004). The relationship between field sensitivity/field independence and the use of vocabulary learning strategies of EFL university students in Taiwan. Unpublished doctoral dissertation, Texas A \& M University.

Chou, Y. (2002). An exploratory study of language learning strategies and the relationship of these strategies to motivation and language proficiency among EFL Taiwanese 
technological and vocational college students. Unpublished doctoral dissertation, University of Iowa.

Coakes, S. J. (2005). SPSS version 12.0 for windows analysis without anguish. Australia: National Library of Australia.

Cross, D. (1983). Sex differences in achievement. System, 11, 159162.

Doering, L. (1999). Language learning strategies of younger second language learners. Unpublished master's thesis, University of Western Ontario.

Douglas, M. O. (1992). Development of orthography-related reading/writing strategies by learners of Japanese as a foreign language. Unpublished doctoral dissertation, University of Southern California.

Ehrman, M. E. \& Oxford, R.L. (1989). Effects of sex differences, career choice, and psychological type on adult language learning strategies. The Modern Language Journal , 73 (1), $1-13$.

Fagerlind, I. \& Saha, L. J. (1989). Education and national development: A comparative perspective. Great Britain: Pergamon Press.

Faizahani Ab. Rahman. (2002). Strategies employed by good and weak English learners and factors affecting the choice of strategies. Unpublished master's thesis, Universiti Kebangsaan Malaysia.

Field, A. (2005). Discovering statistics using SPSS (and sex, drug, and rock $n$ roll). London: Sage Publications.

Gardner, R.C. (1985). Social psychological aspects of language learning: The role of attitudes and motivation. London: Edward Arnold.

Grabe, W. (1986). The transition from theory to practice in teaching reading. In Dubim, F., Eskey, D. E. \& Grabe, W. (Eds.). Teaching second language reading for academic purpose (pp. 25-48). Reading, MA: Addison-Wesley.

Green, J. M. \& Oxford, R.L. (1995). A closer look at learning strategies, L2 proficiency, and gender. TESOL Quarterly, 29 (2), 261-297.

Griffiths, C. (2003). Language learning strategy use and proficiency: The relationship between patterns of reported language learning strategy (LLS) use by speakers of other languages (SOL) and proficiency with implications for the teaching/ learning situation. Unpublished doctoral dissertation, University of Auckland. 
Hair, J. F., Anderson, R.E., Tatham, R. L. \& Black, W.C. (1998). Multivariate data analysis (5th ed.). New Jersey: Prentice Hall.

Hashim, R. A. \& Sahil, S.A. (1994). Examining learners' language learning strategies. RELC Journal, 25 (2), 1-20.

Holt, K. (2005). English proficiency of Chinese students and strategies of language learning. Unpublished doctoral dissertation, University of Kansas.

Hong, K. (2006). Beliefs about language learning and language learning strategy use in an EFL context: A comparison study of monolingual Korean and bilingual Korean-Chinese university students. Unpublished doctoral dissertation, University of North Texas.

Kamarul Shukri Mat Teh. (2006, Ogos). Pengajaran bahasa Arab di Malaysia: Menelusuri arus perubahan. Paper presented at the Bengkel Pengajaran Bahasa Arab. Universiti Darul Iman Malaysia, Kuala Terengganu.

Kamarul Shukri Mat Teh, Nik Mohd Rahimi Nik Yusoff, Mohamed Amin Embi \& Zamri Mahamod. (2008). Penggunaan strategi pembelajaran bahasa berdasarkan tahap pencapaian Bahasa Arab Komunikasi. Proceedings of $3^{\text {rd }}$ International Language Learning Conference, 209-222.

Kamarul Shukri Mat Teh \& Mohd Hazli Yah @ Alias. (2008). Pendidikan bahasa Arab di Malaysia: Tinjauan literatur mengenai tahap penguasaan bahasa. Diges Pendidik, 8 (2), 91-102.

Kamarul Shukri Mat Teh.(2009). Penggunaan strategi pembelajaran bahasa Arab dalam kalangan pelajar sekolah menengah agama. Unpublished doctoral dissertation, Universiti Kebangsaan Malaysia.

Krejcie, R. V., \& Morgan, D. W. (1970). Determining sample size for research activities. Educational and Psychological Measurement, 30 (3), 607-610.

Lan, R. L. \& Oxford, R. L. (2005). Elementary school teachers' beliefs in strategy instruction. Paper presented at the Annual Meeting of Teachers of English to Speakers of Other Languages (TESOL). San Antonio: Texas.

Lu, Y-C. (2007). ESL students' learning motivations and learning strategies. Unpublished Ed., University of South Dakota.

Maccoby, E. E \& Jacklin, C.N. (1974). The psychology of sex differences. Stanford: Stanford University Press. 
McMillan, J. \& Schumacher, S. (2006). Research in education: Eevidence-based inquiry. Boston: Pearson Education.

Mohamed Amin Embi. (1996). Language learning strategies employed by secondary school students learning English as a foreign language in Malaysia. Unpublished doctoral dissertation, University of Leeds.

Mohamed Amin Embi. (2000). Language learning strategies: A Malaysian context. Bangi: Penerbit Universiti Kebangsaan Malaysia.

Mohd Anuar Ramli. (2005). Konsep masyarakat Melayu mengenai gender. Jurnal YADIM, 6, 141-153.

Mohd Nazali Hj Abu Bakar. (1999). Strategi pembelajaran bahasa Melayu di kalangan pelajar tingkatan empat: Satu tinjauan. Unpublished degree thesis, Universiti Kebangsaan Malaysia.

Nakanoko, K. (2004). Oral proficiency and language learning strategies: A preliminary effort to find learner internal factors that enhance oral proficiency of second language learners. Unpublished doctoral dissertation, University of Tennessee.

Nasimah Hj Abdullah, (2006). Permasalahan dalam pembelajaran bagi pelajar diploma pengajian Islam (bahasa Arab) di KUIS dan cara mengatasinya. Prosiding Wacana Pendidikan Islam Siri 5, 199-208.

Nisbet, D. L. (2002). Language learning strategies and English proficiency of Chinese university students. Unpublished doctoral dissertation, Regent University.

Nunan, D. (1999). Second language teaching and learning. Massachusetts: Heinle \& Heinle Publishers.

O’Malley, J. M. \& Chamot, A.U. (1990). Learning strategies in second language acquisition. Cambridge: Cambridge University Press.

Osanai, D. (2000). Differences in language learning strategies between male and female, and also between Asian and Latino ESL students. Unpublished doctoral dissertation, University of Tennessee.

Oxford, R. L. \& Nyikos, M. (1989). Variables affecting choice of language learning strategies by university students. Modern Language Journal, 73 (3), 291-300.

Oxford, R. L. (1986). Second language learning strategies: Current research and implications for practice. Los Angeles: University of California. 
Oxford, R. L. (1989). The role of styles and strategies in second language learning. (Report No EDO-FL-89-07). Washington, DC: ERIC Clearinghouse on Language and Linguistics. (ERIC Document Reproduction Service No. ED 376707).

Oxford, R. L. (1990). Language learning strategies: What every teacher should know. New York: Newbury House.

Oxford, R. L. (1994). Language learning strategies: An update. ERIC Digest. Washington DC: ERIC Clearinghouse on language and linguistics ED376707.

Pallant, J. (2001). SPSS survival manual. NSW: Allen \& Unwin.

Politzer, R. L. (1983). An exploratory study of self reported language learning behaviors and their relation to achievement. Studies in Second Language Acquisition, 6, 54-68.

Punithavalli K. Muniandy. (2003). Strategi pembelajaran bahasa oleh pelajar-pelajar menengah rendah dalam mempelajari bahasa Inggeris sebagai bahasa kedua. Unpublished master's thesis, Universiti Kebangsaan Malaysia.

Radha Nambiar. (1996). Language learning strategies of six Malaysian ESL learners when performing selected language activities. Unpublished master's thesis, Universiti Kebangsaan Malaysia.

Rigney, J. W. (1978). Learning strategies: A theoretical perspective. In. H.F. O’Neil, Jr. (Ed.). Learning strategies (pp. 164-205). New York: Academic Press.

Saupi Man. (2003). Tuntutan-tuntutan asas pengajaran bahasa Arab Komunikasi di luar Negara Arab. Prosiding Wacana Pendidikan Islam Siri 3, 263-275.

Sekaran, U. (1992). Research methods for business: A skalal building approach (2nd ed.). New York: John Wiley \& Sons.

Sima Sayadian. (2008). Exploring the type and frequency of English language learning strategies among TESL students. Proceedings of $3^{\text {rd }}$ International Language Learning Conference, pp. 547-556.

Soars, C. J. (1995). The comprehension strategies of arts and science students learning English as a second language in Malaysian schools. Unpublished master's thesis, Universiti Kebangsaan Malaysia.

$\mathrm{Su}, \mathrm{M}-\mathrm{H}$. (2002). An investigation of English language learning strategies of grade 5-6 students in Taipei, Taiwan. Unpublished doctoral dissertation, Spalding University. 
Supian Mohd Noor. (2003). Strategi pemerolehan ayat satu dasar. Unpublished doctoral dissertation, Universiti Putra Malaysia. Tabachnick, B.G. \& Fidell, L.S. (2001). Using multivariate statistics (4th ed.). Boston: Allyn and Bacon.

Tran, T. (1988). Sex differences in English language acculturation and learning strategies among Vietnames adults aged 40 and over in the United States. Sex Roles 19,747-758.

Wan Abrisam Wan Ahmad. (2002). Tinjauan sikap pelajar terhadap BAK di sekolah-sekolah daerah Machang, Kelantan. Unpublished master's project, Universiti Kebangsaan Malaysia.

Wharton, G. (2000). Language learning strategy use of bilingual foreign language learners in Singapore. Language Learning, 50, 203-243.

Wu, J-H. (2006). Significant factors in college students' motivation and learning strategies in English courses in Taiwan. Unpublished doctoral dissertation, University of the Incarnate Word.

Zamri Mahamod. (2004). Strategi pembelajaran bahasa Melayu di kalangan pelajar sekolah menengah. Unpublished doctoral dissertation, Universiti Kebangsaan Malaysia. 